\title{
GRACILIANO E O PARADIGMA DO PAPAGAIO*
}

\author{
Carlos Alberto Dória **
}

\begin{abstract}
RESUMO
Leinura de Vidas secas $c$ de vários tartos criticos de Graciliano Ramos, ressaltando-se o estudo da missão litcrária, o romance de 30 c o regionalismo entendido an duas modalidades: " problemótico" $e$ " emblemáticor". Destacase a posição fimpar daquelc autor, ao idcntificar a "decadéncia do romance brasilciro", simbolizada no ato de deglutiçāo do papaguio.
\end{abstract}

Unitermos: Literautra brasileira; Vidas secas : regionalismo; diversidadc; simbolo.

Num depoimento a Joāo Condé, Graciliano relata o modo fracionado como compós Vidas Secas, ao longo de 1937. A narrativa, "sem ordem", nasceu da agregaçāo de contos, quando "veio a idecia de juntar as cinco personagens numa novela miúda - um casal, duas crianças e uma cachorra, todos brutos". (1) Acontece que logo nas primeiras páginas da novela o narrador informa: "Ainda na vespera cram scis viventes, contando com o papagaio". O papagaio morrera e Fabiano resolvera "aproveitá-lo como alimento c justificara-se declarando a si mesmo que cle era mudo e inútil. Nāo podia deixar de ser mudo. Ordinariamente a família falava pouco. E depois daquele desastre viviam todos calados, raramente soltavam palavras curtas. O louro aboiava, tangendo um gado inexistente, e latia arremedando a cachorra". Sendo o sexto vivente; o consumo do papagaio $c$, ao mesmo tem-

- Texto preparado para a mesa-redonda prontovida pelo IEA e IEß/USP' por cocasiño das comenıraçōess do centenário de nascimento do escritor Graciliano Ramos, novernluro de 1992.

** Ex-direlor do Arquivo do Eslado, crítico c jormalista.

1 - Ver a edição fac-similar de Vidos Secas, publicada em 1988 pela lïletropaulo en comemoraçĭo às cinqüenta anos de seu liançamento. 
po, um ato de autofagia e de sobrevivencia, contrastando com o impulso anterior, quando Fabiano desejou matar ou abandonar o filho naquele descampado.

O papagaio é presença constante nos escritos de Graciliano Ramos. Como substantivo, como adjetivação, emerge aqui e ali a imagem desse animal incomum suportando o discurso do autor sobre o papel social da linguagem: um deputado é um "poço de manha", "papagueador quando parola com o eleitorado, mudo na cámara, gênero peru"; o autor, que escreve em dois jornais, equilibra-se "como os papagaios"; o leitor, "será um frívolo papagaio loquaz, um inócuo soprador de bolhas de sabão?"; as crianças, obrigadas a lerem gramáticas pedantescas nas escolas, vivem "papagueando os medonhos arcaísmos de além-mar"; o cristianismo deturpado gera idéias exóticas "papagueadas por beatos de Antonio Conselheiro e do Padre Cícero". Falando sobre o processo de criaçāo de suas personagens e, especificamente, sobre Caetés, assim se expressou:

"Até entāo as minhas infelizes criaturas abandonadas incompletas, tinham sido quase mudas, talvez por tentarem expressar-se num portugués certo demais, absolutamente impossível no Brasil. O livro que menciono saiu cheio de diálogos, parece drama. Publiquei-o oito anos depois de escrito, por insistência de Augusto Frederico Schmidt, que tinha virado editor. É uma narrativa idiota, conversa de papagaios".

Enquanto expressão de algo alienado, inútil, caricatural, inumano, a fala do papagaio de Graciliano Ramos sinaliza o terreno fronteiriço entre a consciéncia e o meio social e projcta a linguagem como forma de perdiçăo quando desconectada da vida concreta dos homens. A "linguagem" do papagaio é externa ao animal e carente de significação; inversamente, para o entorno humano, aparece como repetidora da forma, colocando o homem diante do aspecto mecánico, maquinal da própria fala. Onde há pouca fala, o papagaio imita a natureza (abóia e late, arremedando a cachorra); onde há muita fala, como nas escolas, crianças papagueiam "medonhos aracaísmos dc além-mar".

A literatura anterior a 30 assemclha-se ao papagaio, c Fabiano a comeu. Este fato estético fornece o paradigma para comprecndermos a rcvoluçāo promovida pcla gcraçāo de $30 \mathrm{em}$ nossas lctras e, dentro dcla, o papel desempenhado por Graciliano Ramos. Além disso, quando Fabiano comeu o papagaio Graciliano praticamente deu por encerrada sua contribuiçāo à ficçăo brasileira, já que a partir de Vidas Secas (1938) surgem apcnas alguns poucos contos, cronicas e textos de natureza memorialística. Por estas razōes, a ocasiāo, mais do que um

2 - RAMOS, Graciliano. Limher Tonas. Rio de Janeiro, Record, 1975. p. 195. A seguir designado apenas $L T$. 
convite para renovar o prazer de ler Graciliano Ramos, encerra a possibilidade de revermos algumas categorias atraves das quais costumamos interpretá-lo e a seus companheiros de letras.

\section{A literatura enquanto missão}

É da tradiçăo de nossa crítica histórica considerar que a literatura possui uma missão, ponto de vista que se encontra tanto em Sylvio Romero quanto num autor tão distinto como Antonio Cándido. As "missões" da literatura variam no tempo e segundo a ótica do crítico, mas todos parecem buscá-la numa mesma fonte: as relaçōes entre o escritor, ou seu texto, e a história, isto é, a contemporaneidade de sua produção. Talvez este aspecto não seja o mais importante na avaliação de uma obra ficcional, onde sobressai a dimensāo estética, mas é ele que possibilita a história da literatura tal e qual se pratica entre nós. No caso do Romance de 30 o exercício parece particularmente fértil pois, como alguém observou, "E uma dessas datas 'quentes', nas quais a série literária e as outras séries culturais adquirem um alto sentido de sincronizaçăo, permitindo ao historiador o relacionamento crítico do discurso literário com os diversos discursos facilmente detectáveis".

A crítica de natureza histórica ou sociológica, que se debruça sobre o chamado Romance de 30 , no geral ainda nāo concedeu ao texto de Graciliano a temporalidade que marca os clássicos da língua, com Machado de Assis e Eça de Queiroz. A razāo disto reside no fato de que estamos acostumados a ler Graciliano como materializaçăo singular de um genero, o "romance social". Em outras palavras, o que entendemos por Romance de 30 parece sobredeterminar a fruição do texto, conferindo-ihe a dimensāo de "capítulo" da história da literatura, dimensão esta externa à qualidade literária que revela.

Se o Romance de 30 está de fato mais "colado" no amplo contexto cultural da Revoluçāo, entende-se uma das razōes pelas quais a "missão" que a ele se atribui é, em boa medida, extra-literária. Genericamente, espera-se uma postura de compromisso com a realidade, a ponto de Otto Maria Carpeaux chegar a afirmar nos anos 60 - usando fortemente o exemplo da literatura de 30 - que "todas as literaturas latino-americanas são essencialmente políticas". (4) Considerando igualmente o aspecto político, Astrojildo Pereira, lá pelos anos 40 , ao traçar um esboço da história da literatura brasileira, afirmou:

"Em cada naçāo contemporânea há duas naçōes... Em cada cul-

3 - TELES, Gilberto Mendonça. A Crfica e o Romance de 30 do Nordeste. Rio de Janeiro, Atheneu Cultural, 1990. p. 8.

4 - CARPEAUX, Oto Maria. Dialética da Literatura Brasileira. In: Brosil: Tempos Modcmos. Rio de Janciro, Paz e Terra, 1968. p. 157. 
tura nacional há duas culturas nacionais. Estas duas culturas são a expressão, em termos de arte, literatura, filosofia, ciência, etc, de duas correntes de idéias antagonicas que se defrontam e se entrechocam na superestrutura da sociedade: a corrente progressista, revolucionária, e a corrente retrógrada, reacionária; aquela, representando o novo, que surge e se desenvolve, e esta, representando o velho que luta por conservar o seu dominio e sobreviver. Com a aplicação deste critério ao estudo da história da literatura brasileira, podemos nāo só definir as duas linhas contraditórias que demarcam o nosso desenvolvimento cultural, mas também, obviamente, avaliar o verdadeiro sentido de cada obra e situar a posiçāo real de cada autor".

Ora, quando a política, a dimensāo "social" do romance, se torna princípio de classificaçāo e passa a influir na determinação do valor da obra literária compreendemos a razāo daqueles que identificaram na geração de 30 a "inauguração" do romance brasileiro. Ele, contrastando com o passado, está inteiramente apoiado no campo de tensóes criado pela dualidade cultural que o país vive, "a oposiçāo entre as estruturas civilizadas do litoral e as camadas humanas que povoam o interior - entendendo-se por litoral e interior (...) os tipos de existencia, os padróes de cultura comumente subentendidos em tais designaçócs". (6) Assim, a principal característica daquela geração parece ter sido, conforme registrou Antonio Cândido, o "desaburguesamento" da literatura, "realizando e dando sentido humano ao programa estético dos rapazes de vinte e dois".

Esta percepção do papel da literatura cra partilhada pcla grande maioria dos ficcionistas de entāo. Alguns, dentre os quais Graciliano Ramos, assumiram a tarefa árdua de levar adiante o projeto de uma revista "ativa e militante" onde literatura fosse o "oposto a tudo que signifique passatempo, divertimento, jogo, esporte, luxo, bibcló bibliográfico". (8) No programa de Literatura esclarece-se que "viver" $\mathfrak{e}$ sinônimo de participar e que o objetivo específico da publicaçāo era servir a cultura brasileira, contribuindo "com o scu saber, a sua arte e a sua experiencia, para a obra de elcvação do nível cultural das massas". (9)

5 - O texto citado e um manuscrito nĩo datado de Astrojildo Pereiri que se enconlra no ASMOB da Fundazionne Feltrincili, em Milāo, jdentilicido por AIRCL1 A $2,3(4)$.

Devo o ncesso ao texto ao Professor $F$. Del Roio, que e curador do acervo $A S M O B$,

6 - CÂNDIDO, Antonio. Brigada Ligzira. Livr. Marlins Edilora, Säo Paulo, s/d. p. 45.

7 - Idcm, ibidcm, p. 47.

8 - Litcrantra icve Asırojildo Pereira como Diretor Responsfivel. Gracilinno fez parte do Consulho de Redaçāo ao lado de Álvaro Moreira, Anfbal Maclado, Arthur Ruinos, Manuel Bandeirn, Origenes Lessa. Durou de seteribro de 1946 a março de 1948.

9 - Literottra, ano I, $n^{9}$ 1. Rio de Janeiro, sel/1946. p. 2. 
Apesar disso, é significativo que a única contribuição que Graciliano assinou em Literatura tenha se dado no primeiro número, intitulando-se "Decadéncia do Romance Brasileiro". No ensaio em questão afirmou:

"Os nossos melhores romancistas viviam na província, miúdos e isentos de ambiçāo. Contaram o que viram, o que ouviram, sem imaginar exitos excessivos. Subiram muito - e devem sentir-se vexados por terem sido tão sinceros. Nāo voltarão a tratar daquelas coisas simples. Não poderiam recordá-las. Estão longe delas, constrangidos, limitados por numerosas conveniencias. Para bem dizer, estāo amarrados. Certamente ninguém lhes vaj mandar que escrevam de uma forma ou de outra. Ou que năo escrevam. Nāo senhor. Podem manifestar-se. Mas nāo se manifestam. Não conseguem recobrar a pureza e a coragem primitivas. Transformaram-se. Foram transformados. Sabem que a linguagem que adotavam nāo convêm. Calam-se. Não tinham nenhuma disciplina, nem na gramática nem na política. Diziam às vezes coisas absurdas - e excelentes. Já não fazem isso. Pensam no que $e$ necessário dizer. No que é vantajoso dizer. No que é possível dizer".

Trata-se de um escrito de solidão e, ao mesmo tempo, de um divisor de águas para a crítica literária. Através dele Graciliano praticamente encerra o ciclo do Romance de 30 , ao citar nominalmente escritores que tanto admirou, parceiros na visão de mundo, aos quais então imputa a decadencia analisada: Raquel de Queiroz, Jorge Amado, José Lins do Rego, Amando Fontes. Onde e por que se deu essa ruptura com os de sua geraçāo?

É difícil imaginar que aquela época um intelectual brasileiro pudesse ter uma postura que nāo fosse militante no sentido apontado pelo programa da revista Literatura. Mais diff́cil ainda que um comunista escritor concebesse a literatura sem a mediaçāo exclusiva do Partido Comunista. O livro de Jorge Amado sobre Luís Carlos Prestes ( $O$ Cavaleiro da Esperança), ou os herois de Subterraneos da Liberdade, levam esta postura ao paroxismo e são "pedagógicos" no pior sentido da palavra, pois indicam "caminhos de vida " que, se espera, as massas venham a admirar e imitar. Neles o ato de escrever persegue um objetivo político, ao qual se subordina o horizonte estético da literatura. Em outros textos críticos Graciliano observará que Jorge Amado parece pretender suprimir o individuo e a subjetividade, substituindo-os por sujeitos coletivos falsos, absurdos e artificiais.

Parece, pois, que a literatura enquanto missão expressa o papel iluminista que se atribui ao intelectual numa sociedade onde a distáncia entre as elites e a massa se mede não só pela renda, mas também pelo grau de domínio, familiaridade e trato com a cultura universal. A democratizaçāo dos conteúdos desta, em especial aqueles relativos à 
corporificaçăo da cidadania, parece depender de uma postura de "doaçăo", de transferência, em tudo dificultado pelas iniquas estruturas de poder. Espera-se que o intelectual, que conhece, senāo os mecanismos, ao menos os efeitos da dominaçāo, encontre os caminhos práticos para contornar os obstáculos polfticos responsáveis pelo amálgama que funde os interesses agrários ao desempenho das funçōes de Estado. Por esta trilha politiza-se a vida e, com ela, toda a produção intelectual. Em outro texto, (10) procuramos apontar o verdadeiro desespero que acomete o homme de lettre aprisionado nas teias do Estado, produzindo uma "literatura de imitaçāo" e à busca de um atalho que lhe permita "acesso ao real".

\section{Missño literária}

O caminho seguido por Gracilia no aponta num sentido diverso: a libertação da linguagem de quaisquer constrangimentos, inclusive exigências polf́ticas. Assim, năo é apenas um papel novo para a literatura que se vislumbra em sua obra, é a própria relação do intelectual com a cultura de seu povo que se ilumina.

Com o mesmo significado do comentário de Carpeaux, Graciliano se refere à "literatura interessada" (11) para expressar que seus contemporâneos "foram estudar o subúrbio, a fábrica, o engenho, a prisāo da roça, o colégio do professor cambembe. Para isso resignaramse a abandonar o asfalto e o cafe, viram de perto muita porcaria, tiveram a coragem de falar errado, como toda a gente, scm dicionário, sem gramática, sem manual de retórica. Ouviram gritos, pragas, palavrōes, e meteram tudo nos livros que escreveram ". (12) Trata-se da literatura poss-parnasiana, do realismo crítico, do "neonaturalismo", que enfoca o nordeste e corresponde "à missa de Réquiem do Brasil arcaico".

Apesar desse entendimento da literatura como missão, ć um equfvoco supor que este tenha sido o traço principal de sua visão sobre o papel da literatura. O amor a verdade, dirá ao comentar Stıor, de Jorge Amado, é "às vezes prejudicial a um romancista" quando ele vai além de "exibir a miséria e o descontentamento" (14) para introduzir no romance elementos que nāo pertencem ao universo das personagens mas, sim, do autor. Em outro texto, ao falar sobre o cárcere, diz que "existe ali uma razoável amostra do inferno - c, em contato com ela, o ficcionista ganharia ". (15) Aparentemente, portanto, nảo existe

to - Ensaios Emredodos. Sāo Paulo, Siciliano. p. 20 e seg.

11 - RAMOS, Graciliano. LT. p. 119.

12 - Idem, ibidem, p. 93.

13 - CARPEAUX. Oto Maria. Op. cit. p. 160.

14 - RAMOS, Graciliano. LT. p. 94.

15 - Idem, ibident p. 98. 
mediaçāo entre a percepçāo da realidade e os ganhos de qualidade em literatura. "É preciso ser coerente com o meio em que se vive", (16) dirá. Além de "missionário" o escritor parece estar preso ao papel de relator ou "espelho"da realidade.

Mas o propósito de espelhar a realidade é problemático na visāo de Graciliano. Por um lado, em 1915, ele afirma o intuito de "publicar em revistas sérias, onde gente grande colabora, coisas sobre a vida em Palmeira dos fndios, o único lugar que mais ou menos conheço, porque lá vivi quando já tinha idade de pensar" (17), por outro, dez anos mais tarde, questiona o sentido de espelhismo:

"Que valor tem um fato? Que resta dele além das sensaçōes que nos deixa? Quanta coisa há que nāo podemos perceber! E as que apreendemos com certeza não sāo como as sentimos".

Desta indagação resulta a possível inutilidade da litcratura, conforme confessa ao amigo acerca do vício de ler: "nāo sei bem para que serve meter para dentro coisas que de nada nos servem na vida prática". (19)

Apesar do ceticismo sobre a possibilidade de traduzir o real $\mathrm{em}$ ficção, ou sobre a utilidade desta, o ofício de escritor se define com clareza em outro texto:

"Encontrei muitas coisas boas da língua do nordeste, que nunca foram publicadas, e meti tudo no livro. Julgo que produzirāo bom efeito". (20)

É porém numa carta de 1932 que podemos observar a inteireza de seu pensamento sobre o ato de escrever:

"O S. Bernardo está pronto, mas foi eserito todo cm português, como você viu. Agora está sendo traduzido para brasilciro, um brasileiro encrencado, muito diferente desse que aparece nos livros da gente da cidade, um brasileiro matuto, com uma quantidade enorme de expressōes inéditas, belezas que eu nem suspeitava que existissem. Alem do que eu conhecia, andei a procurar muitas locuçōes que vou passar para o papel. O velho Scbastiāo, Otávio, Chico e José Leite me servem de dicionários. O

16 - Idem. Corlas. Ediçăo Especial da MPM Comunicaçōes. Rio de Janeiro, 1980. p. 73. A seguir designado apenas $C$.

17 - Idem. C. p. 59.

18 - Idem. C. p. 78.

19 - Idem. C.p. 71.

20 - Idem. C. p. 124.

Rev. Inst. Est. Bras., SP, 35:19-34, 1993 
resultado $\mathfrak{e}$ que a coisa tem períodos absolutamente incompreensiveis para a gente letrada do asfalto e dos cafés. Sendo publicada, servirá muito para a formaçāo, ou antes para a fixaçāo, da língua nacional. Quem sabe se daqui a trezentos anos eu não serei um clássico?" (21)

Ora, o papel que Graciliano atribui ao escritor é estabelecer a "língua nacional" a partir da observação da realidade circundantc. Uma espécie de etnografia de sua propria gente parece ser o substrato Ja criação literária. Nesta, o texto pousa sobre a textura social conhecida, como a māo sobre o tecido para reconhecer-lhe a trama. No movimento, a linguagem aparece como mediadora e precipita a definiçāo do escritor frente ao mundo que cria. Contrasta com este processo de criação aquele que surpreendemos, por exemplo, em José Américo de Almeida. A Bagaceira é mais um "encontro de águas", uma justaposiçāo de linguagens revelando mundos incomunicáveis no qual a linguagem erudita (do escritor) empresta verossimilhança e autenticidade a "língua do povo", mas o repcrtório de "brasileirismos" nāo logra integrar-se ao universo do autor. (22)

Outra condição que a Graciliano parece neccssário preencher, para bcm executar o ofício literário, e reconheccr os conjuntos diferenciados que in tegram a "língua nacional". Por isso escreve, em tom de blaguc, a Mota Lima Filho pedindo "uma gramática e um dicionário de língua paulista, que nāo entendo, infelizmentec".

O plano ambicioso de "fixaçāo" da língua nacional $e$ o grandc divisor de águas de nossa literatura. Por cste criterio vemos Graciliano se aproximando ou se a fastando de seus colegas de geraçāo, ao traçar o caminho singular de sua obra de ficção. Atraves dela se contrapôs a uma outra literatura, "antipática c insincera que so usa expressöes corretas, só sc ocupa de coisas agradáveis (...) é exercida por cidadāos gordos, banquciros, acionistas, comerciantes, proprictários, individuos que nāo acham que os outros tenham motivo para estar descontentes". (24) Em torno destes "paxás das letras", "donos da litcratura honorária, cscorada e oficial", organizavam-sc os círculos de aduladores e pseudo-críticos. Pelo mesmo critério, nosso autor também se afastará do "rcalismo socialista" abraçado por alguns colegas scus e pela crítica militante; afinal, cram os futuros "paxás das letras" que começavam a surgir à luz do dia.

21 - ldem. C. p. 131.

22 - Ver a respeito o contraste que José Amcrico cstabelece entre a sua literalura e a de Graciliano, em Aspásia Camargo. O Nordestc e a Polfico: dialogo com José Américo de Almeida. Rio de Janciro, Novn Fronleiri, 1984. p. 96.

23 - RAMOS, Graciliano, C. p. 80.

24 - Idcm. $L T$. p. 92. 
Graciliano mostra, assim, uma simbiose entre literatura e poder que se materializa na linguagem bacharelesca e ritual, nas "conversas de papagaios". Por sua vez, os "paxás das letras" correspondem a versāo corporativa do chefe polírico, "os grossos batráquios da lagoa republicana" (25), aos quais se referiu cm 1915 como um "quarto poder" a sintetizar os demais poderes republicanos. Ao uso que estes fazem da linguagem ele atribuía a permanencia $e$ a dificuldade de renovaçāo literária:

"Os políticos maduros, educados na pocsia e na retórica, arrepiavam-se ouvindo sujeitos imberbcs que se agarravam a economia e à sociologia, citavam livros desconhecidos" (26).

Encontra-se, portanto, no autor, além da clara convicçāo de que a missāo do escritor é de natureza estética e se situa exclusivamente no domínio da linguagem, elementos sólidos para a crítica literária. Por um lado podemos vislumbrá-lo como o sujcito que garimpa no linguajar nordestino como um etnógrafo que trabalha com um povo ágrafo mas que tcm como missão integrar esta matéria-prima, através de um trabalho paciente, imaginativo, a uma língua de cultura - o português; por outro lado, a literatura que produz nāo encontra audiência e accitaçāo nos círculos do poder pela simples razāo de que é um contra-poder, destruindo a comunicação que se dá através de formas e conteúdos socialmente ultrapassados. Esta tensāo entre linguagem e poder, na obra de Graciliano, e identificada pela primeira vez em seus cćlebres relatórios enquanto prefcito. A renovaçăo enscjada apareceu no círculo da linguagem burocrática como uma quebra de padrōes na qual Frederico Schmidt póde vislumbrar o escritor. Contra o "espiritismo literário", reconhecia-sc o valor das "inconveniencias" escritas por nordestinos.

Esta mudança, no cntanto, foi impulsionada por fatores exıernos à literatura: a geração de 30 cncontrou seu tcrreno nas transformaçōes havidas na audiência nacional. É do próprio Graciliano o registro histórico:

"as casas editoras multiplicam-se e produzem com abundância. Só a livraria José Olímpio, que recusa todos os dias originais provenientes dos mais a fastados pontos do país, em quatro anos lançou no mercado cerca de um milhāo de volumes, cdiçōes e recdiçöes sucedem-sc (...) romancistas, críticos, historiadores e sociólogos trabalham sem descanso, as vezes com demasiada pressa, queixando-sc todos (...) Temos afinal uma esperança que năo podíamos ter há dez anos. Naqueles tempos longínquos o

25 - Idem. $L T$, p. 9.

26 - Idem. Virentes das Alagoas. Rin de Jinciro, Record. 1975. p. 61. 
Rio de Janeiro e Săo Paulo eram grandes capitais, o resto do pafs valia pouco. E os autores de algumas obras que surgiam timidamente (...) nunca imaginaram, nas suas horas de otimismo e sonho, que se iam tornar de repente figuras nacionais importantes" (27).

Ora, o regionalismo nordestino tornou-se mercadoria de consumo nos grandes centros, através especialmente da literatura produzida pela geração de 30, o que requer que situemos Graciliano frente ao "regional" para uma compreensăo mais exata de seu pensamento. Elc mesmo registrou que "ali pelas imediaçōes de 30 , um nacionalismo crioulo engulhava à lembrança de coisas estrangeiras, condenava a importaçăo, cantava loas ao babaçu, falava com abundância em realidade brasileira. Está claro que pouca gente se ocupou com essa realidade, mas algumas pessoas tentaram conhecé-la, se nāo olhando-a de perto, pelo menos pondo em moda escritores antigos que tinham passado a vida imitando estrangeiros" (28). Assim, nāo se pode falar $\mathrm{cm}$ regionalismo sem qualifica-lo c, a nosso ver, dos anos $20 \mathrm{~cm}$ diante $\mathrm{c}$ possível identificar em gestaçảo duas modalidades de regionalismo nordestino: o regionalis mo problemático e o regionalismo emblematico.

De fato, o "nordeste" como tema da cultura nacional só prosperou nos anos 30. Excetuando Os Sertöes, o olhar do Brasil letrado só se volta para a regiāo a partir do Manifesto Regionalista, de Gilberto Freyre (1926) e A Bagaceira, de José Américo de Almeida (1928). Foi também por volta daquele período que se consumou a integração cconómica da regiāo no contexto nacional, em especial através do atendimento de várias demandas de suas elites pelo poder público. Do ponto de vista cultural, quando isto se deu, vivia-se uma espécic de amnésia nacional em relação ao nordeste, fruto de decadas de abandono e indiferença, vis a vis os principais processos de acumulaçăo de capital. Nos anos 30, o Nordeste aporta na consciencia nacional desprovido de uma "história" na qual todos os brasileiros se reconhecessem. A própria idéa de "passado regional" constituiu-se em armadilha, ao desconectar os processos sociais ali verificados de suas determinaçōes mais gerais. Pode-se dizer que a busca de nexos animava tanto os intelectuais nordestinos quanto as camadas cultas dos grandes centros urbanos, ambos sedentos de inovaçōes capazes de diluir a velha ordem presidida, no plano simbólico, pelos "bacharelismos" e "francesismos" que já não permitiam a identificação com o Brasil circun. dante.

27 - Idem. LT: p. 104-5. Procurei analisar em outro texio ns razōes que respondem pela criaçăo de uma audiencia nacional para o Romance de 30 (A. Carlos Dória, op. cí, cop. 10).

28 - Iden. LT. p. 109. 


\section{O JORNAL}

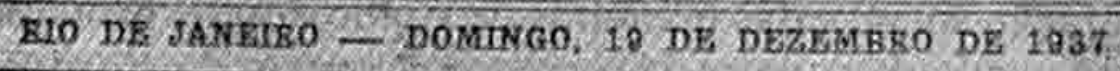

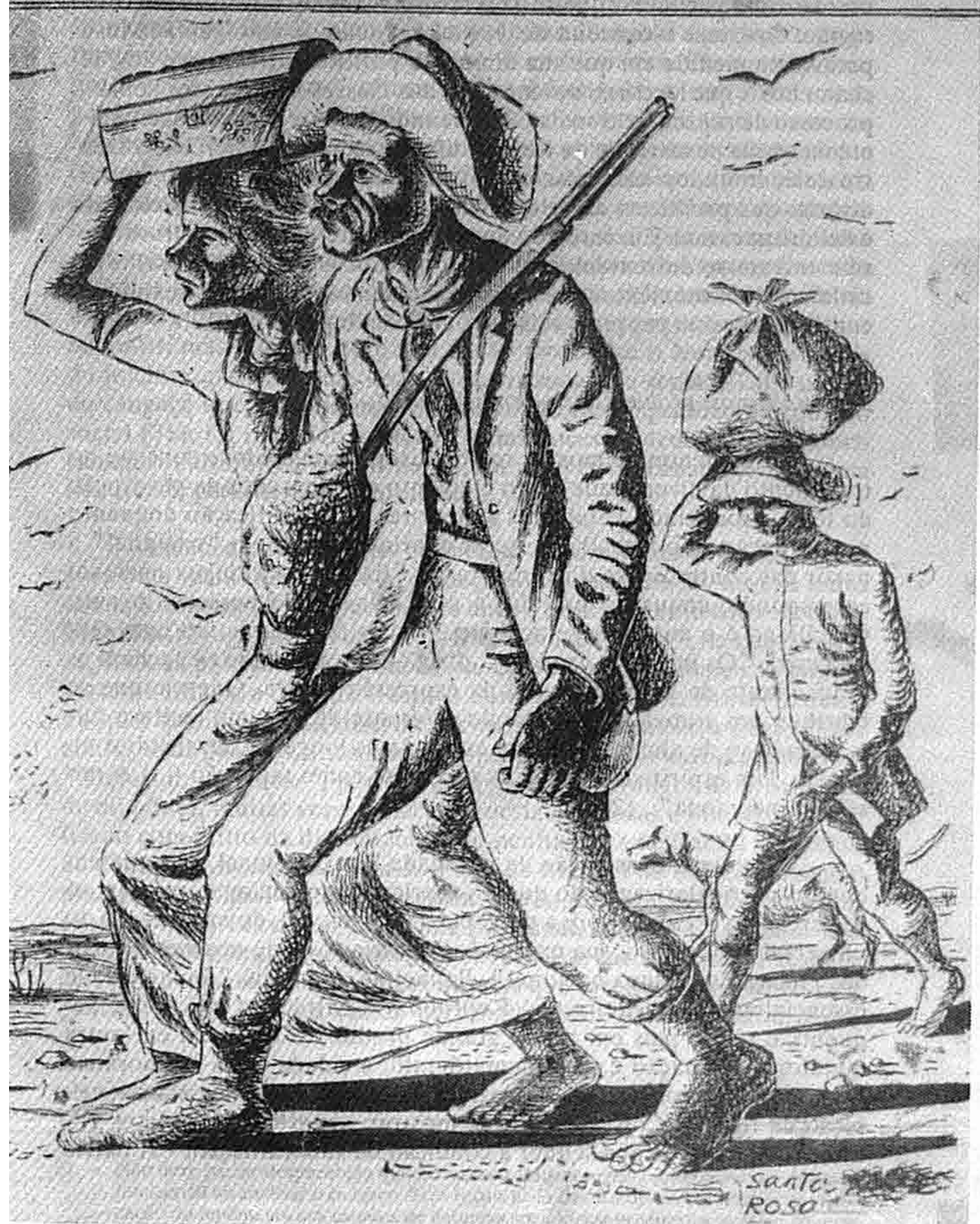

Ilustraçăo de Santa Rosa para "Mudança", conto-capítulo de Vidas Secas. 
É certo que entre a consolidaçāo do Estado nacional e o recente advento da televisāo podemos falar da regiño nordestina como um recorte cultural pertinente. O conceito de regiāo aponta para uma unidade significativa do ponto de vista dos processos produtivos, das formas de interação social e das maneiras de simbolizar. É principalmente neste últímo particular que se dá o reconhecimento do Nordeste como regiāo. Ora, mas o conceito de regiāo e dotado de ambigüidadc insuperável na medida em que sua dimensão política corresponde ao "fechamento" que decorre do controle das classes dominantes sobre o processo de reprodução social, bloqueando a "integraçāo" nacional c até mesmo a penetraçāo de formas diferenciadas de se perceber. Dentro dele, contudo, verifica-sc o confronto de visōes de mundo contraditorias que produzem diferentes "nordestes" para o reconhecimento e deleite nacional. Em torno do que e "nordestc", portanto, travaramse e travam-sc enfrentamentos de importancia para a cultura, cspecialmente nos momentos de crise social, quando sua funçāo $\hat{c}$ explicitar continuidades ou rupturas relacionadas com o presente.

\section{Regionalismos: problemático e emblemático}

O que denominamos de regionalismo problemático consiste no tratamento da divcrsidade como elcmento enriquecedor da percepção do todo, produzindo patamares supcriores de identificação enquanto povo e nação. É o trabalho de tecer continuadamente o "nacional" a partir das contradiçōes que encerra. A "fixaçāo" da língua nacional corresponde, enquanto projeto, a csta mancira de perceber o país. Graciliano ć o autor da geraçăo de 30 mais comprometido com cstc processo. "Os inimigos da vida - dizia - torcem o nariz c fccham os olhos diante da narrativa crua, da cxpressāo áspera. Quercm que sc fabrique nos romances um mundo diferente destc, uma confusa humanidade so de almas (...) Pôcm cssas almas longe da terra, soltas no espaço. Um espiritismo líterário, cxcciente como tapeaçāo (...) A miséria é incômoda". (29)

Para ele, a construçâo da rcalidade local, regional, só sc dá cnquanto particularizaçāo do que é gencricamente nacional, ou seja, só se percebe o rcgional após a percepçāo do nacional, do movimento do universal e, portanto, sua expressāo litcrária só pode ocorrer a partir da "fixaçāo da língua nacional". Palmciras, escreveu, "ć uma cidade essencialmente brasilcira (...) Reproduz-se entrc nos, cm ponto pcqueno, o que o país em ponto grande produz". Ou ainda, cm outra metáfora: "A naçăo é um cincmatografo; a cidade é um cosmorama. Menos que um cosmorama, talvez: um estercoscópio. Na essência, cxibição de figuras. Coisas de ver, de mostrar, exposiçāo de objetos bonitos". Não lhe cscapa sequer a condiçāo de subordinaçāo: "A pátria

29 - Idem, ibidem p. 135. 
é um orangotango; nós somos um sagüi. Diversidade de tamanho, inclinaçōes identicas. Imitaçōes, adaptaçōes, rcproduçōes - macaqueaçōes". O que o Rio de Janeiro imita em grosso nós imitamos a retalho. Usamos um fraque por cima da tanga, alpercatas e meias". (30)

Em oposiçāo a esta maneira de construir o real, ausência de vínculo com o nacional, da mediação do todo a iluminar a parte, é o traço fundamental do outro regionalismo, o emblemático. Ele parte do suposto de que o universo cultural regional é singular e irredutível e que, portanto, não se pode partilhar experiencias mas apenas discursar sobre elas. Este tipo de regionalismo só pode arrancar da tradiçāo, já que entende a regiăo como "anterior" à nação, tanto no plano histórico como no plano lógico. Como corolário, atribui aos influxos da modernidade um papel dissolutivo. Se considerarmos, por exemplo, uma obra monumental como o Dicionário de Folclore de Cámara Cascudo veremos que uma proporçāo muito grande de referéncias remete ao universo cultural nordestino. Isto ocorre não só porque é mais familiar ao autor, mas também porque a naçāo reconhece o Nordeste a partir do folclore, partilha uma visão "folclorizada" da regiāo. Tal e o caso do cangaço que, de fenômeno histórico, de tipo específico de conflito social (31), foi reduzido a "folk" num processo ideológico de imbricamento cultural da regiāo na naçāo, através da construçăo de uma identidade passiva para o nordeste.

A idéa de duas regióes culturais a dividir o país serve de terreno para uma vasta literatura que começa muito antes de 30 , navega junto com o Romance de 30 e permanece após o encerramento daquele ciclo. Fránklin Távora batiza sua obra "literatura do Norte", da qual seriam expressōes particulares $O$ Cabeleira, $O$ Matuto e Lourenço. À mesma vertente filia-se a obra de Gustavo Barroso ("Joāo do Norte"), autor no qual é muito diffcil discriminar entre o ensaísmo e a ficçāo. Esta confusāo de gêneros, aliás, nāo é despropositada. Na auto-denominada "literatura do Norte", por constrangimentos oriundos da proximidade do poder, muitas vezes a ficçāo (poesia ou prosa) $\mathcal{C}$ um recurso utilizado com o fito da dissimulação ou ocultação, suavizando o aspecto de denúncia. Dona Guidinha do Poço, de Manoel de Oliveira Paiva, é um exemplo clássico deste proceder, sendo sabido que o autor se baseou na história real de um crime passional. Mesmo Graciliano não escapou a constrangimentos desta ordem. Em carta a Leonor Ramos, de 1915, promete remeter-lhe as novelas que forem publicadas. "L\& e guarda. E que aludo a certas personalidades... Comprecndes, nāo $\mathfrak{e}$

30 - Iden, ibidcm. p. 60 e 61 .

31 - Näo deve passar despecebido que Graciliano Ramos revela impressionante acuidade intelectual ao analisar o cangaço. Seus textos nada ficam a dever, en termos de explicação do fenomeno, aos esludos de nalureza sociológica produzidos mais de 30 anos após e con base em pesquisas documentais lem ampliss. 
verdade? Náo quero provocar animadversāo de ninguém. É natural". (32) Somente a audiência do Sul podia libertar o novo discurso sobre o Nordeste.

Ora, o "regionalismo tradicionalista" ou emblemático tem seu público no nordeste e só atinge o sul por um processo de ampliaçāo, năo por ruptura. Nesta vertente, a tradiçăo é convocada para fazer sua aparição como folclore, is to é, como conjunto simbólico desprovido de causalidade, como o exótico de nós mesmos. Os vários "nordestes" (o sertăo, a mata, o agreste) assumem, assim, uma funçāo cultural determinada: sinalizam quais as fronteiras dos interesses ameaçados pela modernidade, aquelas que a racionalidade inerente ao capitalismo deve respeitar como limite à sua expansāo para manter o país com a configuraçāo "original".

Os folcloristas partiam de um universo ideológico cristalizado, corrente na percepção das elites sobre a história regional, imune a experimentaçōes. A literatura nordestina folclorizada é um esforço de traduçāo dessa visão de mundo, nāo de criação. Nāo é por acaso, portanto, que necessitam se articular com correntes político-ideológicas estruturadas nacionalmente. Este tipo de literatura estabelece continuidades importantes dentro de um projeto de hegemonia. Mais uma vez, Gustavo Barroso é exemplo típico desta trajetória, atingindo uma audiencia nacional no bojo de um movimento e ideologia polftica de cunho tradicionalista como o integralismo. O trabalho de Gustavo Barroso, assim como o de Câmara Cascudo, é revolver a terra a procura do que julgam jóias da cultura nordestina, e sua "missāo" inclui a construçāo de uma tradição iberica imaginária transplantada para o sertāo. O único movimento literário de alguma expressāo que se apoiou nesta visão de mundo foi o "armorial", cuja expressão máxima co Romance da Pedra do Reino e o Príncipe do Sangue do Vai-e-Volia, de Ariano Suassuna, segundo ele escrito entre 1958 e 1970.

Para esta vertente do regionalismo nāo há uma história a reconstruir, mas apenas crônicas a relatar e, no máximo, monografias sobre famílias sertanejas onde as geraçōes se entrelaçam como rcalidades biologicas e a propriedade da terra emerge como atributo tāo natural quanto a cor da pele. A genealogia e a heráldica ocupam, para as elites nordestinas, o mesmo papel que a historiografia desempenha nos esforços de compreensão do passado.

A expressăo heráldica, genealógica, folclorizada do nordeste, que tem sido uma constante na literatura regional deste século, contrapōe-se fortemente a "missāo" da literatura conforme entendida por Graciliano. Hororizava-se ele com a distinçāo norte/sul, denunciando o caráter da dependência subjacente.

32 - RAMOS, Graciliano. C. p. 59. 
"O que não agrada é ter o senhor Carlos Maul, numa deliciosa pilhéria, aventado a idéia de se desmembrar a nação, como se o desmembramento fizesse desaparecer a prioridade de uma ou da outra parte (...) Para onde mandariam os remotos estados la de cima suas rendas modestas que sāo oferecidas com tanto gosto aos de baixo? Trata-se de saber qual a parte do Brasil que produz mais homens de merito (...) Não parece aos senhores que a discussāo seja cstéril?" (33)

Concretamente, o Romance de 30 oscilou entre estas duas modalidades de regionalismo. Jose Lins do Rego e Raquel de Queiroz deixaram-se, por vezes, seduzir pelo emblemático. A obra de GraciliaIo aparece como o momento mais feliz do Romance de 30 porque jamais se contaminou por este espírito. A ruptura que estabeleceu foi profunda e definiliva, permitindo-lhe situar sua obra no patamar uni-

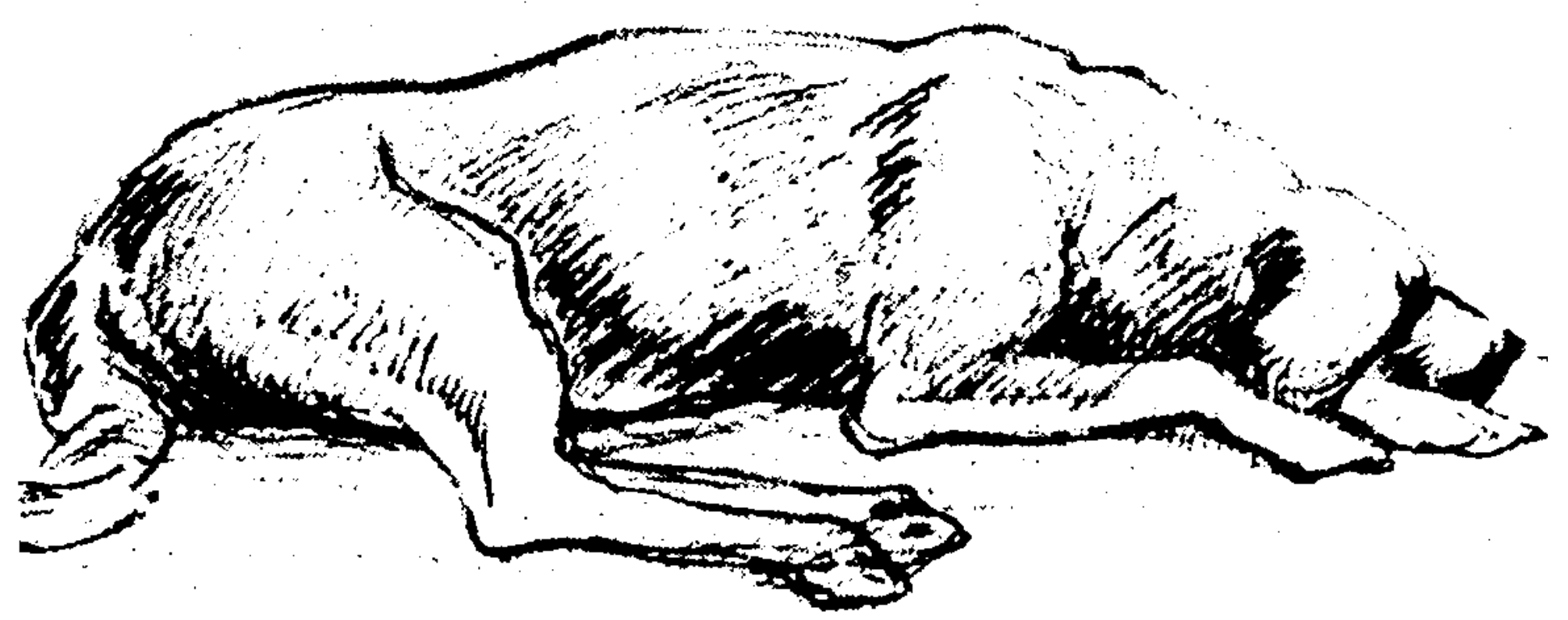

Ilustraçăo para a ediçâo americana de Vidas Secas que recebeu o premio William Faulkner, em 1962.

33 - Idem. LT. p. 44 e 46. 
versal da cultura que caracteriza a nacionalidade no pós-30. Ao cumprir sua "missão", estritamente literária, executada alheia à política mas solidária com o pensamento revolucionário de então, afastou-se daqueles que através da literatura foram tragados pela política e se viram "limitados por numerosas conveniencias", obrigados a dizer o "possível", o "vantajoso", o "necessário", calando a linguagem inconveniente de seus personagens. Graciliano, ao contrário, ao conferir dimensāo simbólica universal ao drama do homem nordestino, como em Vidas Secas ou S. Bernardo, mostra que so é possível pensar o país, sem mutilá-lo, revelando sua diversidade. Ao qualificar o ser brasileiro inaugura a modernidade num sentido amplo, não limitado ao experimentalismo dos modernistas de 22.

Aos aspectos literários aqui registrados somam-se outros que ajudam a explicar a "decadéncia do romance brasileiro". O Estado Novo, através da perseguiçāo movida aos intelectuais como Graciliano, dava acabamento à obra iniciada em 30 de integração das elites nordestinas numa estrutura nacional de poder capaz, ao mesmo tempo, de atender ao nascente industrialismo do sul e as demandas da decadente aristocracia do açúcar. A formaçāo do Institu to do Açúcar e do Álcool (IAAS), do Departamento Nacional de Obras Contra as Secas (DENOCS) e, sob o Estado Novo, do Departamento das Municipalidades junto à presidencia da República, recriaram os canais de barganha entre o poder central e as elites locais. Todos cstes fatores fizeram, inclusive, despencar a audiencia do Romance Je 30. Vidas Secas demorou dez anos para esgotar os miseros mil exemplares da primeira cdição.

O Romance de 30 havia acabado e, com ele, a contribuiçāo ficcional de Graciliano Ramos. Para nāo partilhar da decadência cvidenciada nos novos romances de seus velhos companheiros, prcferiu matar e comer o sexto personagem de Vidas Secas - o papagaio com o qual pclejara por quase vinte anos.

\section{ABSIKACT}

A reading of Vidus Sccas and torions of Graciliano Ramos's critical tonts, emphasizing the literany mission, the 30.tovel and regionalism - tonderstood in no modalities: " problematic" and " cinblematic". The odd position of that author distinguishes isslef by identifying the " decadence" of the Brazilian Noret" with șimbolic swallowing act of the parros

Key-words: Brazilian Lileranure; Vidas Secas: regionalism; dirctsin; symbol. 